\title{
Perception of Olympian and Arjuna Awrdee Zafar Iqbal on Coaching Philosophy and Doping in Sports
}

\author{
Mohd. Tanveer Khan, Reeta Devi
}

\begin{abstract}
The purpose of the present study is to highlight perception of Mr. Zafar Iqbal on Coaching Philosophy and doping in sports for sports person. He led the Indian team as a captain in various International events, prominent among them were Asian Games in 1982, Champions trophy, 1983, and 1984 Los Angeles Olympics. He was honoured by carrying the Indian flag at the youth festival held in Moscow, and later at the opening ceremony of the Los Angeles Olympics. He received the prestigious Arjuna Award in 1983, the highest award given to a sports personality in India.

Keywords : Sports, Coaching, Doping, Arjuna Award
\end{abstract}

\section{HOW TO BE A GOOD COACH}

He strongly believes that the success of a team hinges on the shoulders of a coach. He has recommended the following qualities to be a successful coach:

- Stay calm especially when you are trailing your opponents, being worrisome at the most critical time of the game may prevent you from thinking the best strategy or solution to a problem.

- Try other combination if your plays and strategies are not working. Find the right group of people to bring the momentum to your team.

- Respect your players, hear their suggestions and if their ideas will serve the team in good stead, employ your player's otherwise not. Making someone special by means of empathy will give the team the boost you need.

- Practice, practice and practice. Improve your plays and make research using various references. You may also search for effective plays on the Internet, which has seas of information you may need.

- Carry out your plays very well during practice

Revised Manuscript Received on July 22, 2019.

Dr. Mohd. Tanveer Khan, Assistant Professor, Department of Physical Education and sports science, Lovely Professional University, Jalandhar ,Punjab.

Reeta Devi, Assistant Professor, Department of Physical Education and sports science, Lovely Professional University, Jalandhar ,Punjab and make sure that discipline is well observed on the team.

- Instill good values on your team such teamwork, patience, perseverance and sportsmanship. You will gain their respect and trust doing these.

- You must have the ability to make adjustments.

- Familiarity with one another will build trust and confidence in them and will allow the team members to play as a cohesive unit.

- Psyche them up and motivate your players with inspiring, thought-provoking, compelling and powerful words.

- You are the team's captain of the ship, and all of your actions and decisions will affect the performance of the team. Always have the composure and as much as possible be a role model at all times. Minimize your mistakes.

- Be effective with any resources you have and make the most out of them. Don't complain and be modest with your objectives.

- Give your players more room for improvements. Correct their old bad habits, and wrong forms and movements. Show them how things should be done the proper way, like for instance the correct shooting form in basketball, and the right way to toss or hit the ball in volleyball.

- Show and inculcate them techniques that will set them apart from regular players.

- Explain them their worth in the team. Tell those players with limited playing time why they are not getting much exposure in a nice way and if possible in a private area.

- Win or lose, show them zeal at all times.

- Learn how to take a loss well, for winning is not everything. Learn from your mistakes and try to rebound stronger.

\section{DOPING IN SPORTS}


He observed that in the recent years, use of performance enhancing drugs by professional sportspersons have increased dramatically. Various drugs and steroids are used by sportspersons to improve their performance, reaction time, mental concentration, physical strength etc but most of them ultimately pay a very heavy price for these fleeting benefits often with their own life or lifelong humiliation.

He contended that sports is not a contest of medical and pharmaceutical research and there should be no space for any kind of performance enhancing drugs and anabolic steroids in sports to ensure a level playing field to all the participants. In a fit of rage and under the immense pressure to perform from the coach and the country alike, most of the times, the athlete compromises with his own life.

With a happy heart, he asserted that it is a matter of great concern and shame that the Indian athletes' recent achievements in commonwealth Games have been obliterated by a doping scandal. The recent successes had given a hope to the Indian fans of athletics that India will figure in medal tally with higher ranking, but unfortunately that dream may remain still far fetched. For it, not only the athletes, but also the coaches and the administrators are responsible. As all are in lure of money, name and fame and enduring influence over the sports bodies, resort to short term measures. He further emphasized that if we want to see that the confidence of the New India should reflect in sports as well, the government will also have to come out with an effective sports policy with far sighted impacts. For it, the active cooperation of the elite sportspersons who have set examples with their exemplary behavior will also have to be taken into consideration.

He proudly praised that hockey players the world over, are free from this dreaded practice of employing unethical means for enhancing performance and endangering their health and well being for temporary and fleeting benefits. 
Table 1: Opinion Rating Score in Percent (\%) about How to be a Good Coach by Zafar Iqbal

\begin{tabular}{|c|c|c|c|c|c|c|}
\hline $\begin{array}{l}\text { Sl. } \\
\text { No. }\end{array}$ & Statement & $\begin{array}{l}\text { Strongly } \\
\text { Agree }\end{array}$ & Agree & $\begin{array}{l}\text { Undecide } \\
\text { d }\end{array}$ & $\begin{array}{l}\text { Disagre } \\
\text { e }\end{array}$ & $\begin{array}{l}\text { Strongly } \\
\text { Disagree }\end{array}$ \\
\hline 1 & $\begin{array}{l}\text { Stay calm especially when you are trailing your } \\
\text { opponents, being worrisome at the most critical time of } \\
\text { the game may prevent you from thinking the best strategy } \\
\text { or solution to a problem. }\end{array}$ & $93.50 \%$ & $\begin{array}{l}06.50 \\
\%\end{array}$ & --- & --- & --- \\
\hline 2 & $\begin{array}{l}\text { Try other combination if your plays and strategies are not } \\
\text { working. Find the right group of people to bring the } \\
\text { momentum to your team. }\end{array}$ & $83.33 \%$ & $\begin{array}{l}16.66 \\
\%\end{array}$ & --- & --- & --- \\
\hline 3 & $\begin{array}{l}\text { Respect your players, hear their suggestions and if } \\
\text { their ideas will serve the team in good stead, employ } \\
\text { your player's otherwise not. Making someone } \\
\text { special by means of empathy will give the team the } \\
\text { boost you need. }\end{array}$ & $70.81 \%$ & $\begin{array}{l}29.18 \\
\%\end{array}$ & --- & --- & --- \\
\hline 4 & $\begin{array}{l}\text { Practice, practice and practice. Improve your plays and } \\
\text { make research using various references. You may } \\
\text { also search for effective plays on the Internet, which } \\
\text { has seas of information you may need. }\end{array}$ & $60.00 \%$ & $\begin{array}{l}28.00 \\
\%\end{array}$ & $06.00 \%$ & $04.00 \%$ & $02.00 \%$ \\
\hline 5 & $\begin{array}{l}\text { Carry out your plays very well during practice and } \\
\text { make sure that discipline is well observed on the } \\
\text { team. }\end{array}$ & $60.53 \%$ & $\begin{array}{l}35.87 \\
\%\end{array}$ & $02.69 \%$ & --- & $00.89 \%$ \\
\hline 6 & $\begin{array}{l}\text { Instill good values on your team such teamwork, } \\
\text { patience, perseverance and sportsmanship. You will gain } \\
\text { their respect and trust doing these. }\end{array}$ & $72.96 \%$ & $\begin{array}{l}25.75 \\
\%\end{array}$ & $01.28 \%$ & --- & --- \\
\hline 7 & You must have the ability to make adjustments. & $37.68 \%$ & $\begin{array}{l}40.20 \\
\%\end{array}$ & $21.10 \%$ & $01.00 \%$ & --- \\
\hline 8 & $\begin{array}{l}\text { Familiarity with one another will build trust and } \\
\text { confidence in them and will allow the team members to } \\
\text { play as a cohesive unit. }\end{array}$ & $59.63 \%$ & $\begin{array}{l}29.35 \\
\%\end{array}$ & $11.00 \%$ & --- & --- \\
\hline 9 & $\begin{array}{l}\text { Psyche them up and motivate your players with inspiring, } \\
\text { thought-provoking, compelling and powerful words. }\end{array}$ & $62.78 \%$ & $\begin{array}{l}30.49 \\
\%\end{array}$ & $06.72 \%$ & --- & --- \\
\hline 10 & $\begin{array}{l}\text { You are the team's captain of the ship, and all of your } \\
\text { actions and decisions will affect the performance of the } \\
\text { team. Always have the composure and as much as } \\
\text { possible be a role model at all times. Minimize your } \\
\text { mistakes. }\end{array}$ & $70.81 \%$ & $\begin{array}{l}29.18 \\
\%\end{array}$ & --- & --- & --- \\
\hline 11 & $\begin{array}{l}\text { Be effective with any resources you have and make the } \\
\text { most out of them. Don't complain and be modest with } \\
\text { your objectives. }\end{array}$ & $75.75 \%$ & $\begin{array}{l}19.04 \\
\%\end{array}$ & $05.19 \%$ & --- & --- \\
\hline
\end{tabular}




\section{Perception of Olympian and Arjuna Awrdee Zafar Iqbal on Coaching Philosophy and Doping in Sports}

\begin{tabular}{|c|c|c|c|c|c|c|}
\hline 12 & $\begin{array}{l}\text { Give your players more room for improvements. Correct } \\
\text { their old bad habits, and wrong forms and movements. } \\
\text { Show them how things should be done the proper way, } \\
\text { like for instance the correct shooting form in basketball, } \\
\text { and the right way to toss or hit the ball in volleyball. }\end{array}$ & $65.05 \%$ & $\begin{array}{l}32.71 \\
\%\end{array}$ & $01.11 \%$ & $00.74 \%$ & $00.37 \%$ \\
\hline 13 & $\begin{array}{l}\text { Show and inculcate them techniques that will set them } \\
\text { apart from regular players. }\end{array}$ & $56.60 \%$ & $\begin{array}{l}35.84 \\
\%\end{array}$ & $04.24 \%$ & $02.83 \%$ & $00.47 \%$ \\
\hline 14 & $\begin{array}{l}\text { Explain them their worth in the team. Tell those players } \\
\text { with limited playing time why they are not getting much } \\
\text { exposure in a nice way and if possible in a private area. }\end{array}$ & $51.16 \%$ & $\begin{array}{l}39.06 \\
\%\end{array}$ & $09.76 \%$ & --- & --- \\
\hline 15 & Win or lose, show them zeal at all times. & $61.08 \%$ & $\begin{array}{l}34.38 \\
\%\end{array}$ & $02.71 \%$ & $01.80 \%$ & --- \\
\hline 16 & $\begin{array}{l}\text { Learn how to take a loss well, for winning is not } \\
\text { everything. Learn from your mistakes and try to rebound } \\
\text { stronger. }\end{array}$ & $62.22 \%$ & $\begin{array}{l}35.55 \\
\%\end{array}$ & $01.33 \%$ & $00.88 \%$ & --- \\
\hline
\end{tabular}

Figure- 2

\section{Opinion Rating Score in Percent (\%) about How to be a} Good Coach by Zafar Iqbal

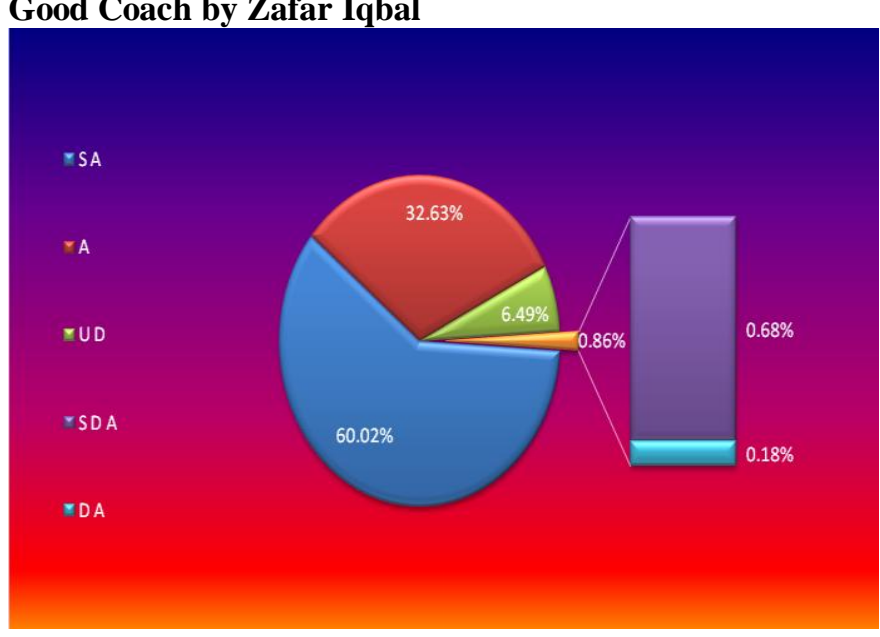

10. Lodhi, H. (1984). Jadidi Olympic. Karachi: International Sports Publications.

11. Mishra, V. (2005). “Jaman Lal Sharma's Life, Personality, Achievements and Contributions in Hockey- A Case Study", Ph.D. Thesis, Lucknow Christian College, Lucknow.

12. Singh, B. (2000). Dronacharya Professor Karan Singh Eminent Physical Educationist and Sports Promoter - A Case Study. Unpublished doctoral Thesis, Punjab University, Chandigarh.

13. Singh, J. (2004). "padma Shree Milkha Singh - Legendary Athlete Sports Administrator and Sports Promoter- A Case Study", Ph.D. Thesis, Punjab University Chandigarh.

14. Singh, R. (2006). "Padma Shree Kartar Singh, Legendary Wrestler, Sports Administrator and Sports Promoter- A Case Study", Ph.D. Thesis, Punjab University, Chandigarh.

15. Singh, S. (2002). “ Padma Shree Sardar Bahadur Singh - Eminent Sports Person, Coach and Sports promoter- A Case Study", Ph.D. Thesis, Punjab University, Chandigarh.

\section{REFERENCES}

1. Khan, M. T. (2012). "Arjuna Awardee Zafar Iqbal Legendary Hockey Player-A Case Study", Ph.D. Thesis, Aligarh Muslim University, Aligarh, India.

2. Denis, A. (1988). "A case study of D.P. Mony, The Olympian Weight Lifter".

3. Dewar, J. D. (1966). The life and professional contribution of James, Naismith. Completed Research in Health Physical Education and Recreation. Vol. 8,

4. Dhillon, P. (2001). "Balbir Singh- Legendary Hockey Player-A Case Study", Ph.D. Thesis, Punjab University, Chandigarh.

5. Dorothy, K. (1996). "Jeans Feiring Williams: His life and contribution to the field of Health, Physical Education and Recreation", completed research in Health, Physical Education and Recreation, vol.6.

6. Dusek P. P. (1981). "Marie Provaznik: Her life and contribution to physical education", Dissertation Abstract International, 46:6, 2558-A. Educational Publishing Inc. p.5

7. Habibullah, M. (2007). "Life History of Olympian Syed Abdussalam and His Contribution to Indian Football, Ph.D. Thesis, Osmania University, Hyderabad.

8. Jerry, S.D. (1987). John H.Scolinos: A Coach for Life. Dissertation Abstracts, International 48:6:1412-A.

9. Kumar, A. (2008). "Dronacharya Awardee M.K Kaushik an Eminent Sportsman, Coach and an Administrator- A Case Study", Ph.D. Thesis Maharishi Dayanand University, Rohtak. 